\title{
Improved methods for the enumeration of heterotrophic bacteria in bottled mineral waters
}

Keywords: BacLight; CTC; Heterotrophic plate counts; Impedance methods; Mineral water

\author{
Rita Ramalho, Joaquim Cunha, Paula Teixeira*, Paul A. Gibbs \\ Escola Superior de Biotecnologia, R. Dr. António Bernardino de Almeida, 4200-072 Porto, Portugal
}

\begin{abstract}
At this time the European Union regulations require that the heterotrophic plate counts (HPC) of mineral waters be assessed at two recovery temperatures: $22^{\circ} \mathrm{C}$ for $72 \mathrm{~h}$ and $37^{\circ} \mathrm{C}$ for $24 \mathrm{~h}$. This procedure is time consuming and expensive. Development of new rapid methods for microbiological assessment of the microbial flora in the bottled water is an industry-driven need.

The objectives of this work were to develop a method for the HPC that utilises only one recovery temperature and one incubation period and evaluate the use of, the LIVE/DEAD ${ }^{\circledR}$ BacLight $^{\mathrm{TM}}$ Bacterial Viability Kit, 5-cyano-2,3-ditotyl tetrazolium chloride (CTC) and impedance methods to enumerate viable bacteria in bottled mineral water.

Results showed that incubation at $30^{\circ} \mathrm{C}$ could be used instead of incubation at $22^{\circ} \mathrm{C}$ and $37^{\circ} \mathrm{C}$. Good correlation exists between counts at $30^{\circ} \mathrm{C}$ and counts at $22^{\circ} \mathrm{C}(r>0.90)$ and all the pathogens important in mineral water analyses grow similarly at $30^{\circ} \mathrm{C}$ and $37^{\circ} \mathrm{C}$ during $24 \mathrm{~h}$.

It was demonstrated that impedance methods might be useful to the mineral water industry as a rapid indicator of microbiological quality of the water.

Results obtained with BacLight and CTC were similar to those obtained with plate counts.
\end{abstract}

\section{Introduction}

In certain parts of the world, disinfection or sterilisation of commercially available mineral waters is not permitted (Anonymous, 1980). Therefore, they generally have high heterotrophic plate counts (HPC) a few days after bottling that should result only from

\footnotetext{
* Corresponding author. Tel.: +351-22-558-0042; fax: +351 22-509 0351.

E-mail address: paula@esb.ucp.pt (P. Teixeira).
}

an increase of bacteria present in the source water. At this time, the European Union regulations require that the HPC be assessed at two recovery temperatures: $22^{\circ} \mathrm{C}$ for $72 \mathrm{~h}$ and $37^{\circ} \mathrm{C}$ for $24 \mathrm{~h}$. The $37^{\circ} \mathrm{C}$ plate count was believed to give an indication of fast-growing bacteria more likely to be related to pathogenic types and the $20^{\circ} \mathrm{C}$ plate count was used for enumeration of characteristic water bacteria that tend to develop slowly. This procedure is time consuming and expensive. It is, therefore, desirable to develop a method for the HPC that utilises only one 
recovery temperature and one incubation period. Development of new rapid methods for microbiological assessment of the microbial flora in bottled water is an industry-driven need.

Direct microscopy has long been established as a rapid method for the enumeration of microorganisms. Fluorochrome stains have become increasingly used because most microorganisms occurring in natural environments cannot be enumerated accurately by traditional plate counts on agar media (Postgate, 1967; Rosak and Colwell, 1987; Gottschal, 1990; Bartscht et al., 1999). Rodriguez et al. (1992) used the reduction of 5-cyano-2,3-ditotyl tetrazolium chloride (CTC) to CTC formazan to directly enumerate metabolically active bacteria in different environmental samples. Boulos et al. (1999) estimated the viable and total counts of bacteria in drinking water using the LIVE/DEAD ${ }^{\circledR}$ BacLight $^{\mathrm{TM}}$ Bacterial Viability Kit, developed by Molecular Probes (Eugene, OR, USA).

The impedimetric technique has been used as a rapid counting method, as an alternative to the standard plate count. The principle of this technique is the measurement of changes occurring in a substrate as evidence of bacterial metabolism. Electrometric growth analysers are now used in the food industry for a wide range of tests (Pirovano et al., 1995) but due to lack of information about comparability with existing standard methods, have not yet been approved for water testing by regulatory authorities. The potential to analyse many samples simultaneously, however, makes this technique attractive for the water industry.

The objectives of this work were to develop a method for the HPC that utilises only one recovery temperature and one incubation period and to evaluate the use of, the LIVE/DEAD ${ }^{\circledR}$ BacLight $^{\mathrm{TM}}$ Bacterial Viability Kit, termed BacLight hereafter, CTC and impedance methods for enumerating viable bacteria in bottled mineral water.

\section{Materials and methods}

\subsection{Water samples}

Three different mineral waters were sampled in this study after various times after bottling $(<12 \mathrm{~h}$ to 18 months) in 1.5-1 polyethylene terephthalate (PET) bottles. Two waters were submitted from two bottling plants in Central Portugal, and the other water samples were from a bottling plant in France. All the samples were randomly selected.

\subsection{Heterotrophic plate count}

The outside of the bottles and caps were disinfected with ethanol and after being very well shaken, the bottles were opened immediately near the flame. Culturable bacteria present in water samples were determined by spread plate $(0.1 \mathrm{ml})$ or by membrane filtration $(0.22-\mu \mathrm{m}$ pore size, $47-\mathrm{mm}$ diameter), for very fresh waters, on the medium developed by Reasoner and Geldreich, which contains $0.5 \mathrm{~g}$ of yeast extract, $0.5 \mathrm{~g}$ of proteose peptone, $0.5 \mathrm{~g}$ of casamino acids, $0.5 \mathrm{~g}$ of glucose, $0.5 \mathrm{~g}$ of soluble starch, $0.3 \mathrm{~g}$ of $\mathrm{K}_{2} \mathrm{HPO}_{4}, 0.05 \mathrm{~g}$ of $\mathrm{MgSO}_{4} \cdot 7 \mathrm{H}_{2} \mathrm{O}$, $0.3 \mathrm{~g}$ of sodium pyruvate, and $15 \mathrm{~g}$ of agar per liter of water (1985; $\mathrm{R}_{2} \mathrm{~A}$; Difco Laboratories, Detroit, MI, USA). This medium proved to be suitable for the recovery of organisms that may be present in water but do not grow in media such as plate count agar due to the low nutrient content of R2A and low incubation temperatures used for this medium (Reasoner and Geldreich, 1985; Noble et al., 1991). Four sets of plates were prepared. Each set was incubated aerobically at a different temperature: $22^{\circ} \mathrm{C}, 25^{\circ} \mathrm{C}$, $30^{\circ} \mathrm{C}, 37^{\circ} \mathrm{C}$. The numbers of autochthonous flora being recovered at each temperature were determined after incubation for 24, 48 and $72 \mathrm{~h}$. Colonies obtained on R2A plates after 24 and $72 \mathrm{~h}$ of incubation at $37^{\circ} \mathrm{C}$ and $22^{\circ} \mathrm{C}$, respectively, where streaked onto R2A plates and incubated at $25^{\circ} \mathrm{C}$ and $30^{\circ} \mathrm{C}$ for 24, 48 and $72 \mathrm{~h}$.

\subsection{CTC reduction assay}

Water samples were filtered through $0.2-\mu \mathrm{m} \mathrm{Nu}$ cleopore polycarbonate black filters (no. 110656).

\subsection{Optimisation of incubation time and CTC con- centration}

Filters were transferred to filter pads soaked in CTC (Polysciences, Warrington, USA) solution at a concentration of 2.0 or $5.0 \mathrm{mM}$. Killed controls were 
prepared by boiling the water samples for $30 \mathrm{~min}$ and also by incubating identical cell suspensions with formaldehyde $(3.7 \% \mathrm{wt} / \mathrm{vol})$ for $5 \mathrm{~min}$ before CTC was added. Experimental and control preparations were incubated for $0.5,1.5,2,3$ and $4 \mathrm{~h}$ at room temperature in the dark and then filtered under vacuum to remove excess dye. Filters were then mounted with low-fluorescence immersion oil (Merck, Frankfurt, Germany) on glass microscope slides. Preparations were examined with the $\times 100$ oil immersion fluorescence objective of a JENAMED 2 epifluorescence microscope (Carl Zeiss, Thornwood, NY, USA) equipped with a mercury HBO 50-W lamp and the illuminator slide BPF 570 for excitation. Red cells (bacteria having an active electron transport system in the respiratory chain) were counted after viewing 10 microscopic fields.

\subsection{Effects of substrates on CTC reduction}

Filters were transferred to filter pads soaked with various carbon substrates obtained from Sigma (St. Louis, MO, USA); these included lactose, formate, glycerol, glucose (all at $10 \mathrm{mmol} / 1$ final concentration) and casaminoacids $(0.2 \% \mathrm{w} / \mathrm{v})$ and these were incubated at room temperature for $30 \mathrm{~min}$. The filters were then transferred to a filter pad soaked with CTC solution at a concentration of $5.0 \mathrm{mM}$ and incubated at room temperature for $1.5 \mathrm{~h}$ as above. Controls were prepared as mentioned above but without incubation with the substrates. Filters were then mounted on glass microscope slides and examined as described previously.

\subsection{BacLight viability kit}

A milliliter of water sample was mixed in an Eppendorf tube with $3 \mu \mathrm{l}$ of the stains mixture (SYTO 9 and propidium iodide; Molecular Probes) prepared according to the manufacturer's instructions, and incubated for $15 \mathrm{~min}$ in the dark at room temperature. The mixture was then filtered through $0.2-\mu \mathrm{m}$ Nucleopore polycarbonate black filters. Filters were then mounted with low-fluorescence immersion oil on glass microscope slides and observed by epifluorescence microscopy as described above for CTC reduction assay. Green cells (cells having an intact membrane) were counted after viewing 10 microscopic fields. When samples bigger than $1 \mathrm{ml}$ were necessary, the water being analysed was filtered through $0.2-\mu \mathrm{m}$ Nucleopore polycarbonate black filters and the filters (still mounted in the filtration unit) were covered with $3 \mu 1$ of the stains mixture in $1 \mathrm{ml}$ of sterile water. After $15 \mathrm{~min}$ in the dark at room temperature, the mixture was filtered and treated as described above.

\subsection{Impedimetric method}

The principle of this method is that subtle changes in the ionic composition of the medium, due to metabolization of uncharged or weakly charged substrates into charged end products, affect its electrical properties (Richards et al., 1978). The detection time (DT) is the time elapsing between the start of a test and the detection of an accelerating impedance signal by the instrument. DT correlates to a bacterial concentration.

Wells containing $0.5 \mathrm{ml}$ of $\mathrm{R} 2 \mathrm{~A}$ broth (R2A minus the agar component) four times concentrated were inoculated with $1.5 \mathrm{ml}$ of water sample (in duplicate) and incubated at $25^{\circ} \mathrm{C}$ and $30^{\circ} \mathrm{C}$ for $48 \mathrm{~h}$. The Bactometer (bioMérieux, Marcy l'Etoile, France) instrument was used for measuring the detection times (different test types allow the user to select the desired impedance signal, i.e., capacitance, conductance, or a combination of these signals, referred to as total impedance; in this work changes in capacitance were used).

\subsection{Statistical analysis}

Data were analysed via the ANOVA methodology using the Statview package (Abacus Concept, Berkeley, CA, USA).

\section{Results and discussion}

Different approaches were taken to assess the viability of bacteria from mineral water.

Figs. 1 and 2 represent the correlation obtained between counts at $25^{\circ} \mathrm{C}$ or $30^{\circ} \mathrm{C}$, respectively, incubated for 48 and $72 \mathrm{~h}$ and EEC recommended HPC $\left(22^{\circ} \mathrm{C}\right.$ for $72 \mathrm{~h}$ plus $37^{\circ} \mathrm{C}$ for $\left.24 \mathrm{~h}\right)$. The best correlations were obtained for $72 \mathrm{~h}$ of incubation 


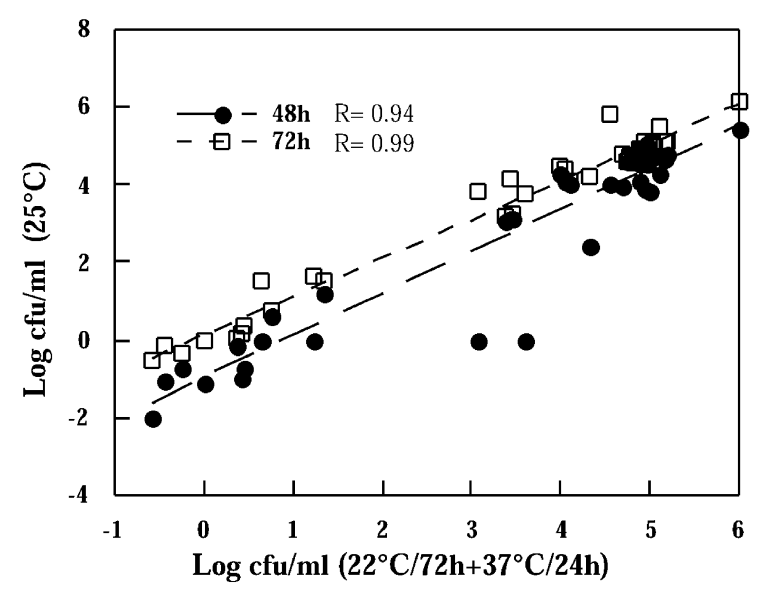

Fig. 1. Relationship between the heterotrophic plate counts of mineral water on $\mathrm{R} 2 \mathrm{~A}$ at $25^{\circ} \mathrm{C}$ for different incubation periods and heterotrophic plate counts of mineral water on $\mathrm{R} 2 \mathrm{~A}$ at $22^{\circ} \mathrm{C}$ for 72 $\mathrm{h}$ plus $37^{\circ} \mathrm{C}$ for $24 \mathrm{~h}$. Data are average of triplicates.

independently of the incubation temperature, $25^{\circ} \mathrm{C}$ or $30^{\circ} \mathrm{C}$. Good correlations $(>0.90)$ were also observed for 48 -h incubation periods at $25^{\circ} \mathrm{C}$ and $30^{\circ} \mathrm{C}$ and for $24 \mathrm{~h}$ at $30^{\circ} \mathrm{C}$. After $24 \mathrm{~h}$ at $25^{\circ} \mathrm{C}$, counts were very low compared with those obtained at $30^{\circ} \mathrm{C}$ (data not shown). It was also observed that all the bacteria that grew at $22^{\circ} \mathrm{C}$ for $72 \mathrm{~h}$ and at $37^{\circ} \mathrm{C}$ for $24 \mathrm{~h}$ were able to grow at $25^{\circ} \mathrm{C}$ and $30^{\circ} \mathrm{C}$ within $48 \mathrm{~h}$ (data not presented). Although a better correlation was observed for $72 \mathrm{~h}$ incubation periods, the industry could use incubation periods of $48 \mathrm{~h}$ at $25^{\circ} \mathrm{C}$ or $30^{\circ} \mathrm{C}$ or even $24 \mathrm{~h}$ at $30^{\circ} \mathrm{C}$ since having results $24-48 \mathrm{~h}$ in advance represents a great improvement and can solve problems of space for product awaiting clearance. Additionally, it is also important to point out that correlations were made between counts at a single temperature and counts at $22^{\circ} \mathrm{C}$ plus $37^{\circ} \mathrm{C}$, the EEC recommended temperatures. In relation to the incubation temperatures, with the exception of $24 \mathrm{~h}$ of incubation, no significant differences were observed between HPC counts at $25^{\circ} \mathrm{C}$ or $30^{\circ} \mathrm{C}$. Previous studies (Schmidt-Lorenz et al., 1990) demonstrated that various isolates from bottled, non-carbonated, natural mineral water had an average optimum temperature of $26^{\circ} \mathrm{C}$. It is, however, recommended to use incubation at $30^{\circ} \mathrm{C}$ since all the indicator pathogens investigated throughout this EC-funded study (Escherichia coli, Pseudomonas aeruginosa, Salmonella typhimurium, Staphylococcus aureus and Yerssinia enterocolitica) grew faster at this temperature than at $25^{\circ} \mathrm{C}$ and were detected after $24 \mathrm{~h}$ of incubation (data not shown).

The reduction of the tetrazolium salt CTC to its fluorescent formazan has been used to count metabolically active and respiring bacteria (LópezAmorós et al., 1997; Smith and McFeters, 1997). All bacteria having an active electron transport system in the respiratory chain will reduce the CTC and form formazan granules, thus being easily enumerated by epifluorescence microscopy. Two CTC concentrations, 2 and $5 \mathrm{mM}$, and different periods of incubation, $0.5,1.5,2,3$ and $4 \mathrm{~h}$, were investigated. Significantly lower counts $(p<0.0001)$ were obtained in the number of CTC-reducing cells when CTC was used at a concentration of 2 than at $5 \mathrm{mM}$, except perhaps after $4 \mathrm{~h}$ incubation (Fig. 3). The highest counts were obtained using a CTC concentration of $5 \mathrm{mM}$ and incubation periods of 1.5, 2 and 3 h. These data confirm results previously obtained by Rodriguez et al. (1992) who suggested that a possible dose-response relationship existed between the CTC concentration and the number of respiring bacteria. Based on these results and those presented in the literature (Rodriguez et al., 1992; Bhupathiraju et al., 1999), data presented hereafter were obtained using CTC at a concentration of $5 \mathrm{mM}$ and incubation periods of $1.5 \mathrm{~h}$.

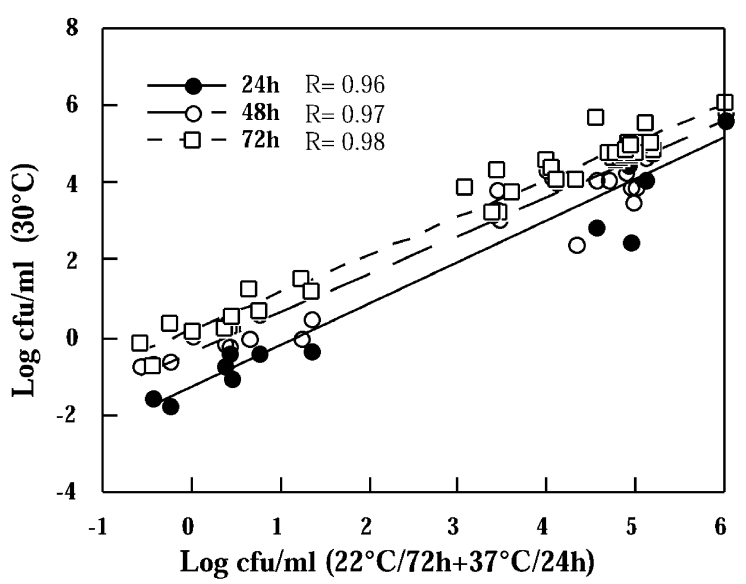

Fig. 2. Relationship between the heterotrophic plate counts of mineral water on $\mathrm{R} 2 \mathrm{~A}$ at $30^{\circ} \mathrm{C}$ for different incubation periods and heterotrophic plate counts of mineral water on $\mathrm{R} 2 \mathrm{~A}$ at $22^{\circ} \mathrm{C}$ for 72 h plus $37^{\circ} \mathrm{C}$ for $24 \mathrm{~h}$. Data are average of triplicates. 


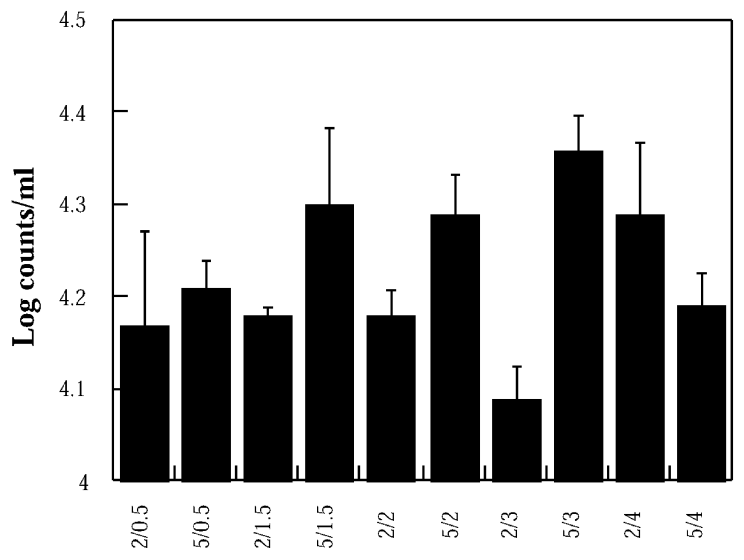

CTC concentration ( $\mathrm{mM}) /$ incubation period (h)

Fig. 3. Effect of different CTC concentration and incubation periods on CTC direct counts of mineral water. Data are average of duplicates and are representative of five independent experiments. Error bars represent standard deviation.

Work done by Rodriguez et al. (1992) and Smith and McFeters (1996) indicated an increased number of CTC-reducing cells in the presence of exogenous nutrients. Bhupathiraju et al. (1999), however, suggested that the addition of exogenous nutrients might not be necessary in CTC reduction assays when optimum concentrations of CTC are used. In this study, significantly higher counts $(p<0.0001)$ in the number of CTC-reducing cells in water samples were obtained in the absence of the different substrates used (Fig. 4). Working with bacteria isolated from a drinking water distribution system, similar observation were made by Coallier et al. (1994) who proposed that the addition of substrate may have produced a nutritional stress on the bacteria which came from oligotrophic environments. Results presented hereafter were obtained using CTC without previous incubation with substrates.

No significant differences $(p<0.0001)$ were observed between counts obtained by CTC and traditional HPC (Fig. 5).

BacLight assesses membrane integrity by selective stain exclusion (Haugland, 1996). This kit contains a mixture of two nucleic acid-binding stains, SYTO 9 and propidium iodide, contained in a solution of anhydrous dimethylsulfoxide. SYTO 9 stains all cells green. Propidium iodide penetrates cells whose cell membrane has been damaged, staining them red. Similar counts $(p<0.0001)$ were observed by BacLight and traditional HPC (Fig. 5).

As observed in Fig. 5, this study demonstrates that both BacLight and CTC can be used successfully to determine the heterotrophic counts in mineral water. The HPC method, the most commonly used in the mineral water industry, was capable of detecting a large percentage of the viable bacteria in mineral waters since a very good correlation was observed between HPC and CTC $(R=0.96)$ or Baclight $(R=0.93)$ under the conditions used in this study (Fig. 5). This did not happen with other drinking waters, whereas a result of various stress conditions imposed on the organisms, e.g. disinfectants such as chlorine, a high percentage of cells enter the so-called viable-non culturable state and cannot be recovered by traditional plate counts (Coallier et al., 1994; Bartscht et al., 1999). Bartscht et al. (1999) showed that most of the bacteria from a natural lake community were in a viable but nonculturable state and were not detected by the CTC reduction method. This was attributed to the toxicity of CTC, which inhibited glucose uptake and respiration. Although the data obtained in this study demonstrated that similar counts were obtained by CTC and traditional HPC, it is necessary to be aware that these results can lead to an underestimation of the number of

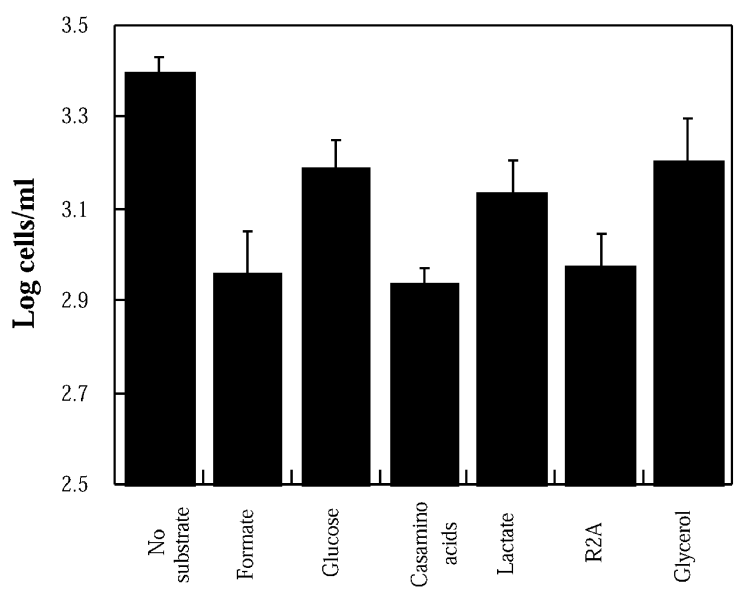

Substrate

Fig. 4. Effects of different substrates on CTC direct counts of mineral water. Data are average of duplicates and are representative of five independent experiments. Error bars represent standard deviation. 


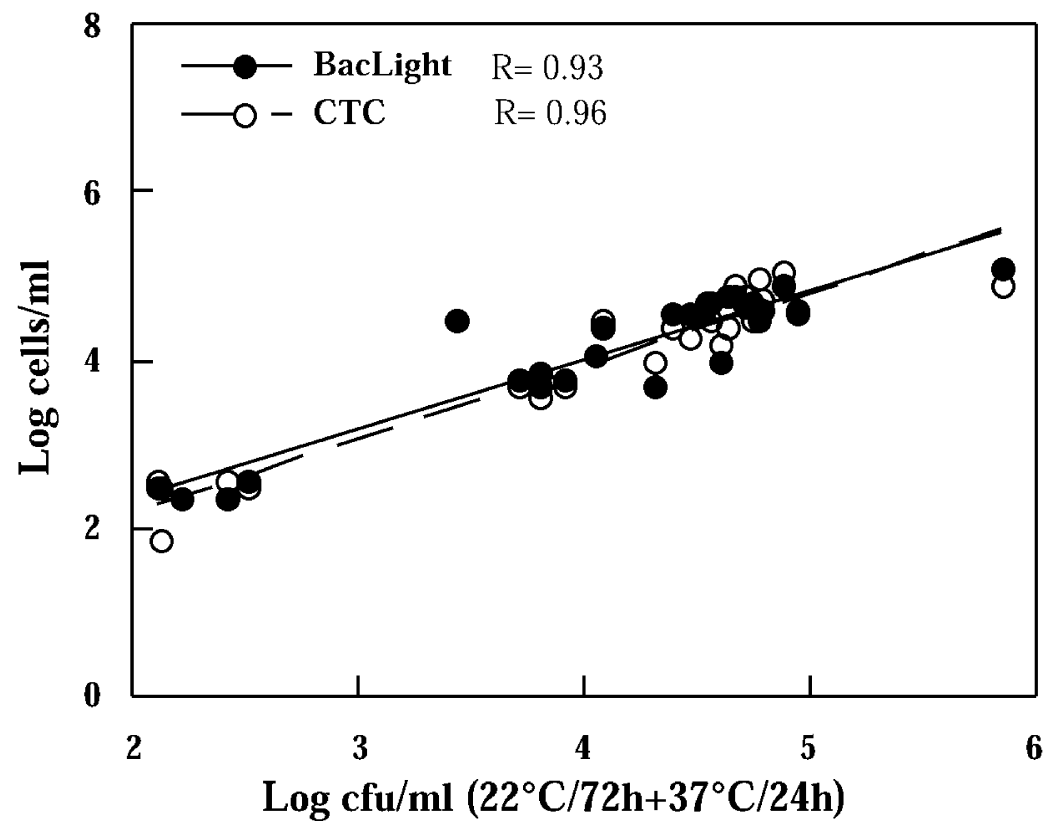

Fig. 5. Enumeration of the autochthonous flora by traditional heterotrophic plate counts of mineral water on R2A and by epifluorescence techniques.

bacterial cells, which are capable of dividing at least once or twice. Microautoradiography or in situ hybridization with $16 \mathrm{~S}$ rRNA-targeted molecular probes should be investigated since Karner and Fuhrman (1997) observed much lower numbers by a CTC reduction method than by these other methods. Although similar counts were observed using traditional and epifluorescence methods, CTC and BacLight were demonstrated to be convenient techniques for the systematic monitoring of the autochthonous flora in the mineral water bottling plant since bacteria might be counted within a few hours rather than in a few days.

The use of impedance methods for heterotrophic counts in mineral water was also investigated. Changing capacitance signal was used since Noble et al. (1991) demonstrated that, in water analysis, this signal resulted in shorter DT than did conductance and total impedance. Additional studies, however, should be done in order to clarify if significant differences are obtained between impedance signals. As observed in Fig. 6, low correlations, 0.70 and 0.57 , were obtained between HPC and the Bactometer DT at $25^{\circ} \mathrm{C}$ and $30^{\circ} \mathrm{C}$, respectively. Longer DT were observed at the lower incubation temperature. A better correlation between HPC and DT, however, was obtained at $25^{\circ} \mathrm{C}$ than at $30^{\circ} \mathrm{C}$. The same observation was made by Noble et al. (1991) who justified their observation by the differences in the generation times of psychrotrophic and mesophilic bacteria, both

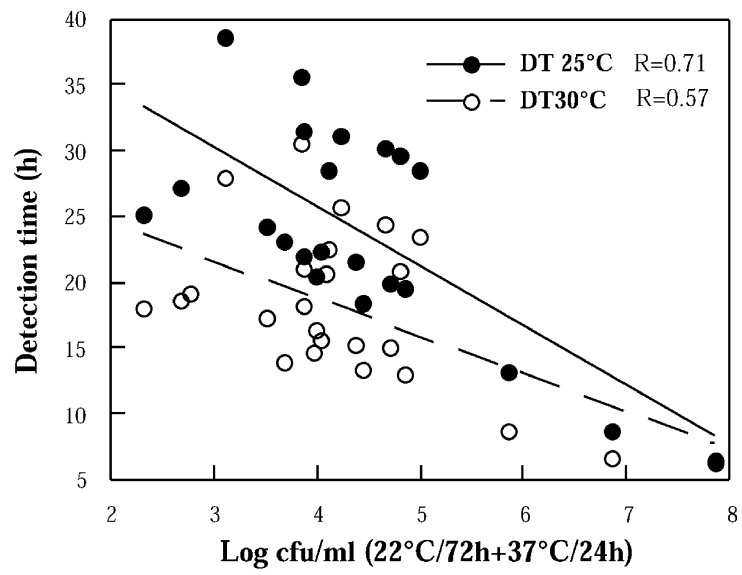

Fig. 6. Relationship between the traditional heterotrophic plate counts of mineral water on R2A and detection times (impedimetric techniques) at $25^{\circ} \mathrm{C}$ and $30^{\circ} \mathrm{C}$. 
types present in water samples. Low incubation temperatures prevent the rapid generation of mesophile bacteria while providing better growth conditions for psychrotrophic bacteria. At higher incubation temperatures, DTs are mostly determined by rapid growing mesophilic bacteria rather than psychrotrophic bacteria. Although low correlations were obtained, it has been demonstrated that the impedance method might be very useful to the mineral water industry as a rapid indicator of microbiological quality of the water. Waters having $100 \mathrm{CFU} / \mathrm{ml}$ or less at $22^{\circ} \mathrm{C}$ for $72 \mathrm{~h}$ and $20 \mathrm{CFU} / \mathrm{ml}$ at $37^{\circ} \mathrm{C}$ for $24 \mathrm{~h}$, the values recommended by the EEC Directives, do not give any DT under the conditions investigated and water samples contaminated with low levels of indicator bacteria (ca. $10 \mathrm{CFU} / \mathrm{ml}$ ) gave DT of less than $24 \mathrm{~h}$ (data not shown). Each mineral water company should also construct its own calibration curve since each particular water has a typical autochthonous flora, which might behave differently in impedimetric analysis. This might explain the low correlations obtained in this study, which was done with samples of three different mineral waters.

\section{Acknowledgements}

This work was financed by an EEC FAIR project CT-96-1037-Improving methods and protocols used to ensure the microbiological quality of bottled mineral waters.

The authors acknowledge Sociedade das Águas de Luso and Danone Water Technology Center for their collaboration.

\section{References}

Anonymous, 1980. Directive du Conseil du 15 Juillet 1980 relative au raprochement des legislation des Etats membres concernant l'exploitation et la mise dans le commerce des eaux minérales naturelles. Annexe 1 (80/777/CEE). J. Off. Communautés Eur. L229, 1-10.

Bartscht, K., Cypionka, H., Overmann, J., 1999. Evaluation of cell activity and of methods for the cultivation of bacteria from a natural lake community. FEMS Microbiol. Ecol. 28, 249-259.

Bhupathiraju, V.K., Hernandez, M., Landfear, D., Alvarez-Cohen, L., 1999. Application of a tetrazolium dye as an indicator of viability in anaerobic bacteria. J. Microbiol. Methods 37, 231-243.

Boulos, L., Prévost, M., Barbeau, B., Coallier, J., Desjardins, R., 1999. LIVE/DEAD ${ }^{\circledR}$ BacLight $^{\mathrm{TM}}$ : application of a new rapid staining method for direct enumeration of viable and total bacteria in drinking water. J. Microbiol. Methods 37, 77-86.

Coallier, J., Prévost, M., Rompré, A., 1994. The optimization and application of two direct viable count methods for bacteria in distributed drinking water. Can. J. Microbiol. 40, 830-836.

Gottschal, J.G., 1990. Phenotypic responses to environmental changes. FEMS Microbiol. Ecol. 74, 93-102.

Haugland, R., 1996. Handbook of Fluorescent Probes and Research Chemicals. 6th edn. Molecular Probes, Eugene, OR.

Karner, M., Fuhrman, J.A., 1997. Determination of active marine bacterioplankton: a comparison of universal 16S rRNA probes, autoradiography, and nucleoid staining. Appl. Environ. Microbiol. 63, 1208-1213.

López-Amorós, R., Comas, J., Castel, S., Vives-Rego, J., 1997. Assessment of E. coli and Salmonella viability and starvation by confocal laser microscopy and flow citometry using rhodamine 123, DiBAC4(3), propidium iodide and CTC. Cytometry $29,298-305$.

Noble, P.A., Ashton, E., Davidson, C.A., William, L.A., 1991. Heterotrophic plate counts of surface water samples by using impedance methods. Appl. Environ. Microbiol. 57, 3287-3291.

Pirovano, F., Piazza, I., Brambilla, F., Sozzi, T., 1995. Impedimetric method for selective enumeration of specific yogurt bacteria with milk-based culture media. Lait 75, 285-293.

Postgate, J.R., 1967. Viability measurements and the survival of microbes under minimum stress. Adv. Microbial Physiol. 1, $1-23$.

Reasoner, D.J., Geldreich, E.E., 1985. A new medium for the enumeration and subculture of bacteria from potable water. Appl. Environ. Microbiol. 49, 1-7.

Richards, J.C.S., Jason, A.C., Hobbs, G., Gibson, D.M., Christie R.H., 1978. Electronic measurement of bacterial growth. J. Phys. E.: Sci. Instrum. 11, 560-568.

Rodriguez, G.G., Phipps, D., Ishiguro, K., Ridgway, H.F., 1992. Use of a fluorescent redox probe for direct visualization of actively respiring bacteria. Appl. Environ. Microbiol. 58, 1801-1808.

Rosak, D.B., Colwell, R.R., 1987. Survival strategies of bacteria in the natural environment. Microbiol. Rev. 51, 365-379.

Smith, J.J., McFeters, G.A., 1996. Effects of substrates and phosphate on INT (2-(4-iodophenyl)-3-(4-nitrophenyl)-5phenyl tetrazolim chloride) and CTC (5-cyano-2,3-ditolyl tetrazolium chloride) reduction in Escherichia coli. J. Appl. Bacteriol. 80, 209-215.

Smith, J.J., McFeters, G.A., 1997. Mechanisms of INT (2-(4 iodophenyl)-3-(4-nitrophenyl)-5-phenyl tetrazolim chloride) and CTC (5-cyano-2,3-ditolyl tetrazolium chloride) reduction in Escherichia coli K-12. J. Microbiol. Methods 29, 161-175.

Schmidt-Lorenz, W., Bischofberger, Th., Cha, S.K., 1990. A simple nutrient-tolerance (NT) test for the characterization of the different types of oligocarbotolerant and oligocarbophile water bacteria from non-carbonated mineral water. Int. J. Food Microbiol. 10, 157-176. 